\title{
NEW ZEALAND'S AGRICULTURAL SECURITY SYSTEM
}

\author{
R.J. IVESS ${ }^{1}$ and E.R. FRAMPTON ${ }^{2}$ \\ ${ }^{1}$ MAF Regulatory Authority, P.O. Box 2526, Wellington \\ ${ }^{2}$ MAF Regulatory Authority, P.O. Box 24, Lincoln, Canterbury
}

\begin{abstract}
New Zealand is an island country and as such, enjoys the benefits of effective, natural quarantine barriers. However, New Zealand is a trading country that imports a wide range of produce from a large number of countries from all parts of the world, which places a continual threat on its plant health status. In order that trade can continue without jeopardising New Zealand's plant health status, an integrated agricultural security system, ranging from offshore treatment to exotic pest response has been developed.

Keywords: quarantine pest, plant health status, International Plant Protection Convention (IPPC), WTO Agreement on the Application of Sanitary and Phytosanitary Measures
\end{abstract}

\section{INTRODUCTION}

The NewZealand Ministry of Agriculture (MAF) endeavours to implement technically justified, costefficient, agricultural security practices sufficient to maintain New Zealand's plant health status. In order to optimise efficacy and ensure that the cost of access into New Zealand is directed to the areas where activities should be undertaken, an integrated approach to agricultural security has been adopted, with a number of components. This integrated approach also has the advantage of recognising the efficacy of offshore systems which as well as reducing risk for produce exported to New Zealand, may also be utilised as a means of reducing post entry requirements and hence allowing more rapid distribution of genetic material.

The components of the integrated New Zealand agricultural security system are:

- international agreements/standards for phytosanitary measures;

- New Zealand import health standards;

- supply country's export certification system;

- borderinspection;

- biosecurity clearance;

- plant pest surveillance; and

- $\quad$ exotic disease and pest response.

\section{INTERNATIONAL AGREEMENTS/STANDARDS}

New Zealand is a contracting party to the FAO International Plant Protection Convention (IPPC). This Convention applies mainly to quarantine pests involved in international trade and requires that any phytosanitary measures imposed by an importing country be transparent and technically justified. As well as IPPC requirements, New Zealand has an obligation to comply with the conditions/requirements of the WTO Agreement on the Application of Sanitary and Phytosanitary Measures (WTO SPS Agreement). These measures essentially reinforce the requirements of the IPPC, in that any phytosanitary measures must be transparent, technically justified and sufficient only to protect plant health (as opposed to protecting a domestic market). The process by which New Zealand MAF develops import health standards on a country:crop basis ensures that its phytosanitary measures are completely transparent. Where possible, New Zealand's phytosanitary measures, as specified in the import health standards, are based on the international standards for phytosanitary measures (ISPM). Where international standards do not exist, New Zealand (MAF) has developed its own, based on the UPPC and the WTO SPS Agreement. 


\section{NEW ZEALAND IMPORT HEALTH STANDARDS}

In this component of the New Zealand MAF system, organisms associated with the produce are categorised and phytosanitary measures developed accordingly. As the category (quarantine or non-quarantine) that a pest falls into will determine the risk management procedures to be adopted, it is necessary that a transparent and technically justified pest risk analysis (PRA) procedure be utilised. New Zealand bases its PRA procedure on theISPM: Guidelines for Pest Risk Analysis and has developed procedural documents governing this process.

The format established for all New Zealand's import health standards is aligned with the requirements of the Biosecurity Act 1993 and applies the definitions contained in the FAO Glossary of Phytosanitary Terms. Any import health standard contains the following information:

- documentation requirements;

- the list of organisms associated with the crop, categorised intobilateral quarantine arrangement pests, additional declaration pests, phytosanitary inspection pests, non-quarantine pests and non-plant pests.

- $\quad$ pre-export activities required (e.g. field inspection, pest control activities);

- inspection required by the supply country national plant protection organisation (NPPO) for quarantine pests;

- additional declarations to the phytosanitary certificate. These confirm that any required pre-export activities have been undertaken;

- transit requirements;

- requirements to be met on arrival in New Zealand (includes inspection method and contingencies for the interception of any quarantine pest); and

- $\quad$ any requirements to be met post entry (e.g. post entry quarantine for some nursery stock before biosecurity clearance can be given).

The resultant import health standard is communicated to the supply country in order that the NPPO may develop an appropriate export certification system. New Zealand MAF has identified three groups of quarantine pests and requires different measures to be undertaken accordingly. These groups are bilateral quarantine arrangement pests, additional declaration pests and phytosanitary inspection pests.

\section{SUPPLY COUNTRY'S EXPORT CERTIFICATION SYSTEM}

In meeting New Zealand's import health standards, the supply country's export certification system becomes an integral part of the New Zealand agricultural security system. Unlike many countries where the major means of phytosanitary control of imported plant material is to sample the consignment on arrival and make a decision based on the result of what was detected, New Zealand considers that the onus is on the exporting country to ensure that its plant material meets New Zealand's phytosanitary requirements before it leaves that supply country. This places a responsibility on New Zealand MAF to ensure the supply country is completely informed of any phytosanitary requirements (in the form of import health standards) and that the country has the opportunity to discuss/debate technical justification.

\section{BORDER INSPECTION}

Being an island country, New Zealand is able to implement relatively effective phytosanitary control systems. Border inspection is used to check compliance with New Zealand's import health standards for all possible pest entry pathways, i.e. passengers, vessels, mail and commercial cargo consignments. For plant material, should a quarantine pest be detected, the importer is given the option of re-ship, destruction of the consignment or, if available, treatment. A feedback system is implemented that informs a supply country whenever a quarantine pest is intercepted.

Before imported produce can be released for general (uncontrolled) distribution within New Zealand, it must first be given biosecurity clearance by New Zealand MAF. Biosecurity clearance can only be given if an inspector is satisfied that all the requirements of the import health standard (including post entry) have been met. 


\section{PLANT PEST SURVEILLANCE}

Plant pest surveillance may be considered the backstop for New Zealand's border inspection. It is recognised that not all pest pathways can be totally controlled (the most notable being smuggling) and should a pest of major concern enter New Zealand, it is important that it be detected before it establishes (so that the eradication option may be considered). Any active plant pest surveillance system developed (e.g. fruit flies) is such that it is most able to detect the pest of concern at the earliest opportunity.

A second role of surveillance is to support and justify pest categorisation. Any pest that New Zealand categorises as a quarantine pest, requires some form of action (hence cost) to be taken by an exporting country and so New Zealand MAF must be able to demonstrate the absence of these. This role is clearly enunciated in the recent revision of the IPPC in that Article VI, which relates to Requirements in relation to imports, item (j) specifically states:

Contracting parties shall, to the best of their ability, conduct surveillance for pests and develop and maintain adequate information on pest status in order to support categorization of pests, and for the development of appropriate phytosanitarymeasures. This information shall be made available to contracting parties, on request.

Toenable New Zealand to maintain accurate information concerning its plant health status, New Zealand MAF:

- has developed (and will continually update) a surveillance database, referred to as the Plant Pest Information Network (PPIN), that will eventually list all organisms associated with plants and plant products in New Zealand; and

- maintains an annual crop survey programme for nominated products (based on (draft) ISPM: Guidelines for Survey and Monitoring Systems).

\section{EXOTIC PEST AND DISEASE RESPONSE}

If a targeted pest (e.g. fruit flies) is found in New Zealand, an eradication programme based on a pre-defined management strategy will be implemented. A second area involves the action taken on the detection of other (than targeted) new pests in New Zealand. A measured response may be initiated following the identification of an unwanted organism, as it would be referred to in the Biosecurity Act 1993. This would involve firstly, the development of a strategy for pest containment (and if considered attainable, eradication), followed by implementation of that strategy. In lieu of any ISPMs, New Zealand MAF has developed its own standards in this area. 